\title{
Latitudinal variation in phlorotannin contents from Southwestern Atlantic brown seaweeds
}

\author{
Glaucia Ank ${ }^{1}$, Bernardo Antonio Perez da Gama ${ }^{1}$, Renato Crespo Pereira $^{\text {Corresp. } 1,2}$ \\ 1 Departamento de Biologia Marinha, Universidade Federal Fluminense, Niterói, Rio de Janeiro, Brazil \\ 2 Instituto de Pesquisas Jardim Botânico do Rio de Janeiro, Rio de Janeiro, Brazil \\ Corresponding Author: Renato Crespo Pereira \\ Email address: rcrespo@id.uff.br
}

Phlorotannins are primary and/or secondary metabolites found exclusively in brown seaweeds, but their geographic distribution and abundance dynamic are not very well understood. In this study we evaluated the phlorotannin concentrations among and withinspecies of brown seaweeds in a broad latitudinal context (range of $21^{\circ}$ ) along the Brazilian coast (Southwestern Atlantic), using the Folin-Ciocalteau (FC) colorimetric method. In almost all species (16 out of 17 ) very low phlorotannin concentrations were found $(<2.0 \%$, dry weight for the species), confirming reports of the typical amounts of these chemicals in tropical brown seaweeds, but with significantly distinct values among 7 different and probably highly structured populations. In all 17 seaweed species (but a total of 25 populations) analyzed there were significant differences on the amount of phlorotannins in different individuals (ttest, $p<0.01$ ), with coefficients of variation (CV) ranging from 5.2 to $65.3 \%$. The CV, but not the total amount of phlorotannins, was significantly correlated with latitude, and higher values of both these variables were found in brown seaweeds collected at higher latitudes. These results suggest that brown seaweeds from higher latitudes can produce phlorotannins in a wider range of amounts and probably as response to environmental variables or stimuli, compared to low latitude algae. 
Latitudinal variation in phlorotannin contents from Southwestern Atlantic brown seaweeds

Glaucia Ank $k^{1}$ Bernardo Antonio Perez da Gama ${ }^{1}$ \& Renato Crespo Pereira ${ }^{1,2}$

${ }^{1}$ Departamento de Biologia Marinha, Instituto de Biologia, Universidade Federal Fluminense, P.O. Box 100.644, CEP 24.001-970, Niterói, Rio de Janeiro, Brasil.

${ }^{2}$ Instituto de Pesquisas Jardim Botânico do Rio de Janeiro, Rio de Janeiro, Brazil.

Corresponding Author:

Renato Crespo Pereira

Departamento de Biologia Marinha, Instituto de Biologia, Universidade Federal Fluminense, Morro do Valonguinho, s/n, P.O. Box 100.644, CEP 24.001-970, Niterói, RJ, Brasil. Present address: Instituto de Pesquisas Jardim Botânico do Rio de Janeiro, Rio de Janeiro, Brazil

\section{Email address: rcrespo@id.uff.br}

\section{Abstract}

Phlorotannins are primary and/or secondary metabolites found exclusively in brown seaweeds, but their geographic distribution and abundance dynamics are not very well understood. In this study, we evaluated phlorotannin concentrations among and within species of brown seaweeds across a broad latitudinal context (range of $21^{\circ}$ ) along the Brazilian coast (Southwestern Atlantic), using the Folin-Ciocalteau (FC) colorimetric method. We found very low phlorotannin concentrations (typically $<2.0 \%$ dry weight) in almost all species (16 out of 17), confirming reported concentrations in tropical brown seaweeds, but with significant differences among seven different and probably highly structured populations. In all 17 seaweed species analyzed (representing a total of 25 populations), we found significant differences in the amount of phlorotannins in different individuals $(t$ test, $p<0.01$ ), with coefficients of variation $(\mathrm{CV})$ ranging from 5.2 to $65.3 \%$. The $\mathrm{CV}$, but not the total amount of phlorotannins, was significantly correlated with latitude, and higher values for both these variables were found in brown seaweeds collected at higher latitudes. Our results suggest that brown seaweeds from higher latitudes can produce phlorotannins in a wider range of concentrations relative to those at low latitudes, probably in response to environmental stimuli.

\section{Introduction}

Phlorotannins are polymers derived from a simple monomer, phloroglucinol, found exclusively in brown seaweeds (Targett \& Arnold 1998 2001). These water-soluble secondary metabolites constitute a special class of polyphenols that may exhibit multifunctional ecological roles, acting as a herbivore deterrent (Pereira \& Yoneshigue-Valentin 1999), antifouling agent (Plouguerné et al. 2012), antioxidant (Cruces et al. 2012), UV protector (Henry \& Van Alstyne 2004), and a chelating agent of toxic heavy metal ions (Karez \& Pereira 1995). However, these chemicals may also be classified as primary metabolites when they are structural components of cell walls (Schoenwaelder \& Clayton 1999). In fact, phlorotannins found inside the cells of brown seaweeds are stored in small vesicles called physodes, and these chemicals may exude into the environment due to their water solubility (Jennings \& Steinberg 1994) where they can have several vital ecological roles (e.g. Pereira et al. 1990). As cell wall components, where 
they form a complex with alginic acid, they are insoluble (Schoenwaelder 2002, Koivikko et al. 2005). Given the smaller amounts of cell-wall-bound phlorotannins compared to soluble phlorotannins, the major function of these chemicals appears to be secondary metabolites (Koivikko et al. 2005).

The concentration of phlorotannins in brown seaweeds is known to be highly variable in several modes and at various scales, supposedly in response to the dynamics of biotic and abiotic environmental conditions (Jormalainen et al. 2003). For example, concentrations may vary in response to environmental factors, either biotic such as herbivory (Hemmi et al. 2004) and epibiosis (Plouguerné et al. 2010) - or abiotic - such as temperature (Cruces et al. 2012), irradiance (Cruces et al. 2013), nitrogen concentrations (Pavia \& Toth 2000), bathymetric variation, and immersion time in the intertidal range (Connan et al. 2004). Phlorotannin content can also vary according to intrinsic aspects of brown seaweeds, such as individual size and age (Pavia et al. 2003), and tissue type (Plouguerné et al. 2012).

Another interesting aspect relating to the distribution, abundance, and function of phlorotannins is the latitudinal differences in content of these chemicals among brown seaweeds living along large temperate-tropical gradients (Steinberg 1989, Van Alstyne \& Paul 1990). High concentrations of these compounds have been found in species from high latitudes (Ragan \& Glombitza 1986, Steinberg \& Paul 1990, Steinberg \& Van Altena 1992, Hay \& Steinberg 1992, Steinberg 1992). For example, species of Fucales and Laminariales that are abundant in temperate benthic communities, and Dictyotales found both in temperate and tropical regions, exhibit this biogeographic trend. The most common brown seaweed species in temperate Australasia exhibit more than $10 \%$ of total phlorotannins (Steinberg 1989), whereas there are both phlorotannin-rich and -poor species in some temperate regions of South Africa (Anderson \& Velimirov 1982, Tugwell \& Branch 1989), northwestern Pacific (Katayama 1951, Estes \& Steinberg 1988), and the European North Atlantic (Ragan \& Glombitza 1986).

Many species of brown seaweeds from North America exhibit low levels of phlorotannins, ranging from 0 to $2 \%$ of algal dry weight (Ragan \& Glombitza 1986). This range is found mainly in kelps dominating both the sublittoral and lower littoral environments (Steinberg 1992). In contrast, as the most abundant organisms found in littoral and upper sublittoral regions, fucoids commonly contain higher phlorotannin contents (more than $4 \%$ dry weight) (Steinberg 1985, Van Alstyne 1988, Denton et al. 1990, Targett et al. 1992). In general, brown seaweeds from North America exhibit broad variation in phlorotannin contents linked to the bathymetric gradient, with littoral fucoids and subtidal kelps showing high and low levels of these compounds, respectively (Estes \& Steinberg 1988, Steinberg 1992).

In general, the intensity of selective pressures on organisms increases with decreasing latitude, including higher herbivory and epibiosis (Railkin 2004, Targett \& Arnold 1998). Consequently, tropical seaweeds are hypothesized to have evolved more effective chemical defenses (Van Alstyne \& Paul 1990, Targett et al. 1992). Contrary to this trend, phlorotannins are sometimes absent or present in very low concentrations in seaweeds from tropical environments (Steinberg 1989, Van Alstyne \& Paul 1990, Pereira \& Yoneshigue-Valentin 1999). There is only one report of high amounts of these compounds in brown seaweeds from low latitudes (Targett et al. 1995).

However, in almost all studies, the quantification of phlorotannins is based on an analysis of distinct specimens of brown seaweed species extracted together, masking possible variability in amounts of these chemicals in each individual of a population. However, intra-populational variation in seaweed-derived chemicals can be of great magnitude and ecological significance (Oliveira et al. 2013).

Along the Brazilian coast, the few studies on phlorotannin contents in brown seaweeds are united in the fact that they typically reveal low concentrations (Fleury et al. 1994), and that they may be capable of inhibiting grazing when they occur at higher concentrations (Pereira \& Yoneshigue 1999). The extensive Brazilian coast covers a broad latitudinal range of the Southwestern Atlantic and harbors numerous species of brown seaweeds. It comprises several environments suitable for exploring chemical defenses via a biogeographic approach. To date, most studies in Brazil have only reported average phlorotannin concentrations, so there is no information concerning the variation within populations or among populations from different latitudes. Thus, more in-depth analysis is needed, as tropical species could have the same mean value as temperate seaweeds, but exhibit greater standard deviation. Here, we hypothesized that contents of brown seaweed phlorotannins would exhibit latitudinal variation along the Brazilian coast. Our aim was to compare the mean phlorotannin concentration, as well as the coefficient of variation, among 
92

and within species of brown seaweeds across a broad latitudinal context along the Brazilian coast to evaluate the hypothesis that species from low latitudes exhibit lower amounts of these chemicals relative to those from high latitudes.

\section{Materials \& Methods}

\section{Study organisms and collection localities}

Brown seaweeds were collected from along the Brazilian coast (Instituto Chico Mendes de Conservação da Biodiversidade - Authorization Number 27001-2) in order to best represent various populations of the same species and individuals in each population from the different localities (Fig. 1, Table 1): Giz Beach $\left(6^{\circ} 10^{\prime} \mathrm{S} ; 35^{\circ} 05^{\prime} \mathrm{W}\right)$ at

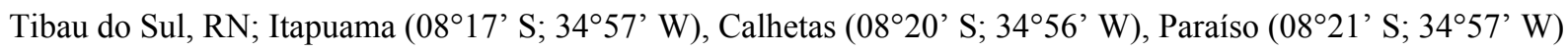

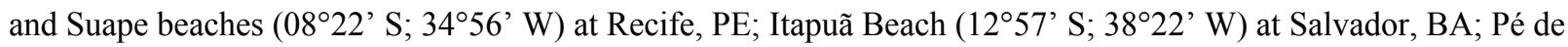

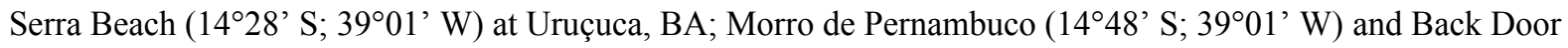

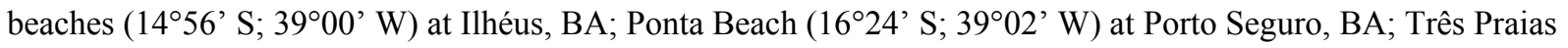

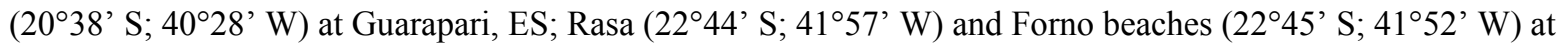
Armação dos Búzios, RJ; and Canasvieiras Beach (27²5’ S; 48²8’ W) at Florianópolis, SC. We collected individuals of the following species: Canistrocarpus cervicornis (Kützing) De Paula \& De Clerck, Colpomenia sinuosa (Mertens ex Roth) Derbés \& Solier, Dictyopteris delicatula J.V. Lamouroux, D. polypodioides (A.P. De Candolle) J.V. Lamouroux, Dictyota ciliolata Sonder ex Kützing, D. crispata J.V. Lamouroux, D. dichotoma (Hudson) J.V. Lamouroux, D. mertensii (Martius) Kützing, D. pfaffii Schnetter, Lobophora variegata (J.V. Lamouroux) Womersley ex E.C. Oliveira, Padina gymnospora (Kützing) Sonder, Sargassum filipendula C. Agardh, S. stenophyllum Martius, S. ramifolium Kützing, S. vulgare C. Agardh, S. vulgare var. nanum E. De Paula, S. vulgare var. vulgare, Spatoglossum schroederi (C. Agardh) Kützing, and Stypopodium zonale (J.V. Lamouroux) Papenfuss.

\section{Extraction}

After collection, the seaweeds were freeze-dried, ground to powder and, before extraction, subjected to a lipidremoval treatment using $1 \mathrm{~mL}$ hexane for $3 \mathrm{~min}$ (Koivikko et al. 2007). Extraction was then carried out for $2 \mathrm{~h}$ using $10 \mathrm{ml}$ of acetone:water (7:3) for $100 \mathrm{mg}$ of each sample of dry alga. Each extract was centrifuged for $10 \mathrm{~min}$ at 3500 rpm and filtered. Acetone was evaporated off at room temperature and the aqueous extract was again centrifuged. The supernatant was frozen for further quantification.

\section{Phlorotannin quantification}

We used the Folin-Ciocalteau (FC) colorimetric method to quantify phlorotannin concentration, by which $1 \mathrm{~N}$ FC reagent was added to a diluted aliquot of the extract and, after $3 \mathrm{~min}, 20 \%$ sodium carbonate was added. After 45 min in the dark, phlorotannins were quantified in a Shimadzu UV1800 spectrophotometer, at $750 \mathrm{~nm}$, using a standard curve obtained with phloroglucinol $\left(\mathrm{r}^{2}=0.99\right)$, which is a monomer that absorbs under the same patterns as the polymers (phlorotannins) derived from it (Steinberg 1988). Three aliquots of each extract were prepared for quantification, and the total phlorotannin concentration is expressed in \% per dry weight (DW) of the seaweed.

\section{Statistical analysis}

The coefficient of variation was calculated as the ratio of the standard deviation to the mean $(\mathrm{CV}=\delta / \mu .100)$ in order to compare the amount of variation in phlorotannin contents observed within different populations of seaweeds. Total phlorotannin content of different populations from the same species was assessed by independent $t$ test or, when $n$ was unequal, with an independent $t$ test with separate variances, which is more appropriate when considering groups of different sample sizes. In the case of more than two populations from the same species, we conducted a unifactorial ANOVA followed by the post-hoc Student Newman-Keuls test (SNK).

\section{Results}

\section{Amounts of phlorotannins and their inter-populational variability}

Total phlorotannins ranged from 0.05 to $4.30 \%$ (average \pm standard deviation) for the 17 brown seaweed species we studied (dry weight), encompassing a total of 25 populations (Table 2). 
Lobophora variegata was the only species that did not show significant inter-populational variation, with mean phlorotannin contents of $0.91 \%( \pm 0.22), 0.13 \%( \pm 0.00)$ and $0.81 \%( \pm 0.53)$ for the populations from Recife, Salvador and Porto Seguro, respectively $(p=0.06 ; F(2.17)=3.29$; ANOVA).

We found $0.13 \%( \pm 0.01)$ and $0.18 \%( \pm 0.00)$ of phlorotannins per dry weight of seaweed in the populations of Canistrocarpus cervicornis from Recife and Armação dos Búzios, respectively, with these values being significantly different ( $p<0.0001 ; t(8)=6.75$; $t$-test for independent samples with separated variances).

Populations of Colpomenia sinuosa collected at Porto Seguro and Armação dos Búzios had average phlorotannin contents of $0.07 \%( \pm 0.01)$ and $0.24 \%( \pm 0.02)$, respectively, with significant inter-populational variation $(p<0.0001 ; t(5)=16.62 ; t$-test for independent samples with separate variances).

In Dictyopteris delicatula, we recorded significant differences in the amounts of phlorotannins between the studied populations $(p \approx 0 ; F(3.19)=45.76$; ANOVA). Individuals from Recife contained a mean phlorotannin content of $0.14 \%( \pm 0.01)$, whereas specimens from Salvador, Porto Seguro and Guarapari had mean contents of $0.08 \%( \pm 0.01), 0.13 \%( \pm 0.01)$ and $0.12 \%( \pm 0.02)$, respectively.

Individuals of Dictyota mertensii from three collection sites also contained significantly different phlorotannins contents $(p<0.0001 ; F(2.24)=16.71$; ANOVA). The Recife population exhibited a mean phlorotannin content of $0.19 \%( \pm 0.01)$, whereas populations from Guarapari and Armação dos Búzios presented mean values of $0.10 \%( \pm 0.01)$ and $0.18 \%( \pm 0.03)$, respectively.

Populations of Padina gymnospora also differed in their mean phlorotannin contents $(p<0.0001 ; F(8,34)$ $=9.78$; ANOVA), with the highest amount found in specimens from Florianópolis at $0.58 \%( \pm 0.30)$. In the population of that same species from Tibau do Sul, we recorded $0.40 \%( \pm 0.02)$ of phlorotannins per dry weight, whereas the mean value for the population from Recife was $0.07 \%( \pm 0.01)$. At Ilhéus, the population from Uruçuca exhibited 0.19\% ( \pm 0.01) phlorotannin content, whereas those from Morro de Pernambuco Beach and Back Door Beach had values of $0.26 \%( \pm 0.02)$ and $0.05 \%( \pm 0.00)$, respectively. Mean phlorotannin content of the population at Porto Seguro was $0.13 \%( \pm 0.05)$, whereas it was $0.22 \%( \pm 0.09)$ and $0.58 \%( \pm 0.30)$ for those at Armação dos Búzios and Florianópolis, respectively.

We also observed significant variation in amounts of phlorotannins for populations of Sargassum filipendula ( $p \approx 0 ; t(17)=-8.75 ; t$-test for independent samples with separate variances), with individuals of the population from Salvador having significantly less phlorotannins $(0.09 \% \pm 0.00)$ than those from Uruçuca $(0.38 \% \pm$ 0.10). Similarly, populations of Sargassum vulgare were significantly different in terms of their phlorotannin contents $(p \approx 0 ; F(5.52)=80.01$; ANOVA $)$, with mean contents of $0.13 \%( \pm 0.01)$ and $0.14 \%( \pm 0.04)$ for the Recife and Uruçuca populations, respectively. Individuals of $S$. vulgare from Morro de Pernambuco Beach (Ilheus) presented a phlorotannin content of $0.73 \%( \pm 0.15)$, whereas specimens from Back Door Beach, also at Ilhéus, had $0.20 \%( \pm 0.11)$. Exemplifying the diversity in phlorotannin contents, the population of Sargassum vulgare from Porto Seguro had the lowest value at $0.10 \%( \pm 0.02)$ and the highest value was found for the population from Armação dos Búzios at $1.10 \%$ ( \pm 0.31$)$.

Only one population was sampled for each of the following species: Dictyopteris polypodioides and Sargassum ramifolium from Guarapari showed a mean phlorotannin content of $0.22 \%( \pm 0.01)$ and $0.17( \pm 0.06)$, respectively. For Dictyota ciliolata it was $0.14 \%( \pm 0.02)$, for Dictyota crispata it was $0.14 \%( \pm 0.04)$, for Dictyota dichotoma it was $0.11 \%( \pm 0.01)$, all hailing from Porto Seguro. Dictyota pfaffii from Salvador - BA presented $0.10 \%( \pm 0.02)$ of phlorotannins per dry weight, and for Sargassum stenophyllum from Florianópolis - SC it was $0.45 \%$ ( \pm 0.19$)$. Mean phlorotannin content of Stypopodium zonale was $1.72 \%( \pm 0.49)$, and the highest concentration of phlorotannins found for all studied species was in Spatoglossum schroederi at $4.30 \%( \pm 0.78)$. Variation in phlorotannin contents within populations and across a latitudinal gradient

Intra-populational analyses were carried out for 25 populations (Table 2) of 14 seaweed species (Table 1). For all analyzed populations, we identified a significant difference in the amount of phlorotannins among the individuals that comprised them ( $t$ test, $p<0.01$ ), with coefficients of variation $(\mathrm{CV})$ ranging from $5.2 \%$ to $65.3 \%$ (Table 2). CV was higher in populations collected from higher latitudes, but the correlation though significant $(p<$ $0.005)$ was relatively weak $(r=0.55)$ (Fig. 2). 
We assessed phlorotannin contents in brown seaweeds sampled along a broad latitudinal range, from $2^{\circ}$ to $22^{\circ}$ of southern latitude, representing from Recife to Rio de Janeiro, respectively (Table 2). The highest phlorotannin contents were found in brown seaweeds collected at higher latitudes, but the correlation between amounts and latitude was weak and non-significant (Fig. 3, $r=0.23 ; p=0.15$ ).

\section{Discussion}

The phlorotannin contents found in the brown seaweeds we investigated were typically very low $(<2.0 \%$ dry weight, DW), with only one exception, Spatoglossum schroederi for which we recorded $4.30 \%$ DW. These results reinforce a pattern that seems to be typical of tropical areas, including the Brazilian coast, in which low values of phlorotannins have been reported for several brown seaweeds belonging to different orders, ranging from 0.2 to $2.17 \%$ DW (e.g. Pereira \& Yoneshigue 1999, Pereira et al. 1990, Fleury et al. 1994). Low contents of these chemicals, varying from 0.19 to $1.62 \% \mathrm{DW}$, were also found in some brown seaweeds from Guam and neighboring areas of the tropical Pacific (Steinberg \& Paul 1990, Van Alstyne \& Paul 1990). Moreover, low levels of phlorotannins (ranging from 0.2 to $1.77 \%$ DW) have been found in Sargassum spp. and Turbinaria spp. at two tropical sites, Tahiti and the Great Barrier Reef, Australia, respectively (Steinberg 1986).

Brown seaweed phlorotannins have been reported as defensive chemicals against herbivores in some studies (e.g. Jormalainen \& Ramsay 2009), but only when they occur at concentrations higher than $2.0 \%$ DW, i.e. levels commonly found in species from temperate regions (Ragan \& Glombitza 1986). However, the evidence for this defensive property of phlorotannins remains disputed, with reports supporting (Van Alstyne \& Paul 1990) and refuting (Steinberg \& Paul 1990) this role. The low levels of phlorotannins in tropical seaweeds may be due to these chemicals having limited impact on tropical fish herbivory, given that fishes from the Great Barrier Reef do not consume more phenolic-poor tropical species than phenolic-rich species (Steinberg \& Paul 1990). However, contradicting this latter finding, phlorotannin-rich seaweeds were not consumed by fishes in Guam (tropical Pacific region), though extracts from phlorotannin-poor species were also not eaten (Van Alstyne \& Paul 1990). Moreover, phlorotannins in amounts higher than those usually found in the Brazilian brown seaweed Sargassum furcatum can inhibit herbivory (Pereira \& Yoneshigue 1990). However, according to our results, almost all of the seaweeds we studied probably do not employ this kind of chemical defense to prevent herbivory, since phlorotannin contents were usually lower than $2.0 \%$ DW.

The hypothesis of a latitudinal gradient of phlorotannin contents is based on the assumption that herbivory pressure increases with decreasing latitude and that production of seaweed chemical defenses is selected by the action of herbivores. Accordingly, defensive chemicals should be more common and effective in tropical seaweeds. Although chemical defenses are commonly associated with herbivore abundance and pressure, no study has conclusively demonstrated that herbivores impose selective pressures on the production of secondary metabolites (Van Alstyne \& Paul 1990). Moreover, phlorotannins may be present in brown seaweeds for reasons other than herbivore defense, since they have been suggested to exhibit other ecological roles, such as protecting against shortwave UV radiation (Pavia et al. 1997), and as anti-fouling agents (Plouguerné et al. 2010, 2012).

It would be difficult to establish a clear correlation between the latitudinal variability in phlorotannin production by brown seaweeds solely with the different pressures of herbivory along the Brazilian coast, even knowing that this kind of variation exists and that the seaweeds we studied were collected from a broad latitudinal range (ca. $21^{\circ}$ ). Importantly, it remains controversial if herbivory pressure selects for chemical defense production (Pereira \& Da Gama 2008), even across a global tropical-temperate latitudinal gradient or along the Brazilian coast (Longo et al. 2014). In addition, it is known that concentrations of secondary metabolites may vary according to temperature (Sudatti et al. 2011), nutrient availability (Puglisi \& Paul 1997), light (Pavia et al. 1997), salinity (Kamiya et al. 2010, Sudatti et al. 2011), and herbivory (Weidner et al. 2004). Thus, since the seaweeds we studied are also subjected to unknown variability in all these external conditions, it is perhaps not surprising that we did not establish a direct causal effect between phlorotannin content and latitude.

The extent of genetic control over chemical defense production remains poorly understood. For example, phlorotannin content was demonstrated to be due to genotypic variation in Fucus vesiculosus (Jormalainen et al. 2003, Jormalainen \& Honkanen 2008, Koivikko et al. 2008), as well as for terpenes in the red seaweeds Laurencia 
nipponica (Masuda et al. 1997, Abe et al. 1999) and Delisea pulchra (Wright et al. 2004). If phlorotannin production is genetically modulated, geographic distance and gene flow would likely contribute to the variation in the content of these phenols in our studied species. In general, seaweeds are considered poor dispersers because their gametes and spores only survive for a few days in the water column (Santelices 1990, Sosa \& Garcia-Reina 1993). Limited gene flow has been reported for diverse seaweed species (Wright et al. 2000, Faugeron et al. 2001, 2004, Zuccarello et al. 2001; Van der Strate et al. 2003), and small-scale dispersal distances are a significant factor in the differentiation of seaweeds (Tatarenkov et al. 2007). Thus, if secondary metabolite production is an inherited character, geographic distance should act as a barrier to gene flow and give rise to quantitative differences in phlorotannin production.

Abiotic differences among collection sites could also support the hypothesis that different field conditions contribute to the between-site variability in phlorotannin concentrations for each of the algal species we studied. Temperature is a determining factor for the survival, geographic distribution, and reproduction of seaweeds (e.g. Padilla-Gamiño \& Carpenter 2007), and it is also responsible for many responses of their primary metabolism, such as photosynthesis, growth (Nishihara et al. 2004), nutrient absorption (Tsai et al. 2005), and secondary metabolism (e.g. Sudatti et al. 2011). Thus, given the reduced gene flow known for seaweeds (e.g. Wright et al. 2000) and the different environmental conditions along the Brazilian littoral coast, populations of the same species we studied here could be highly structured, explaining in part the results we obtained. Accordingly, our field data reinforce the idea that genetic heterogeneity contributes to quantitative variation of secondary metabolism and that our sampled populations may represent ecotypes.

The intra-populational variability in the amounts of defensive chemicals we report here corroborates the findings of the few previous studies that investigated this topic in the red seaweeds Portieria hornemannii (Matlock et al. 1999), Delisea pulchra (Wright et al. 2000) and Laurencia dendroidea (Sudatti et al. 2006). However, those studies did not assess as broad a latitudinal context as we did. Our study also reinforces the importance of analysis at the intra-population level (i.e. variation among specimens), since most studies of seaweed chemical ecology overlook this element of chemical variation by examining pooled extracts and/or substances obtained from groups of individuals. Developmental (Bowers \& Stamp 1993), environmental (Agrell et al. 2000), and genetic (Berenbaum \& Zangerl 1992) traits all represent sources of variation that can explain the diversity of plant chemical phenotypes. Moreover, in seaweeds, life-history phases (see Vergés et al. 2008), ontogenetics (Paul \& Van Alstyne 1988), and chemical races (Abe et al. 1999) may also be included as sources of secondary metabolite variability. In our analysis, the specimens belonged to the sporophytic life-history phase and were approximately of the same size. However, we cannot rule out the possibility that chemical races exist among the individuals of each population we studied.

\section{Conclusion}

Overall, our results show that latitude does not explain the variability in total amounts of phlorotannins found in each population of the brown seaweeds we studied along the Brazilian coast, but the significant intraspecific differences in production of these chemicals we report may be important to understanding the ecological drivers of this defensive chemistry in seaweeds. Based on characteristics of the Brazilian coast (Floeter \& SoaresGomes 1999), the higher phlorotannin levels we recorded in populations from higher latitudes may represent a greater capacity for these seaweeds to respond to seasonal stimuli. Since envrionments in low latitudes exhibit little seasonal variation, the need for seaweeds in these zones to vary production of these chemicals may be lessened. Thus, brown seaweeds at higher latitudes are more likely to modulate chemical defense production in response to stimuli than those in tropical regions where the environmental conditions are more constant. However, we assert that further studies of intra-populational variability in chemical defense are warranted in the context of marine chemical ecology.

\section{References}

Abe T, Masuda M, Suzuki T, Suzuki M. 1999. Chemical races in the red alga Laurencia nipponica (Rhodomelaceae, Ceramiales). Phycological Research 47:87-95 DOI 10.1046/j.14401835.1999.47220155.x. 
Agrell J, McDonald EP, Lindroth RL. 2000. Effects of $\mathrm{CO}_{2}$ and light on tree phytochemistry and insect performance. Oikos 88:259-272 DOI 10.1034/j.1600-0706.2000.880204.x.

Anderson RJ, Velimirov B. 1982. An experimental investigation of the palatability of kelp bed algae to the sea urchin Parechinus angulosus Leske. Marine Ecology 3:357-373 DOI 10.1111/j.1439-0485.1982.tb00284.x.

Berenbaum MR, Zangerl AR. 1992. Genetics of secondary metabolism and herbivore resistance in plants. In: Rosenthal GA, Berenbaum MR, eds. Herbivores: their interactions with secondary plant metabolites. Academic Press, New York.

Bowers MD, Stamp NE. 1993. Effects of plant age, genotype, and herbivory on Plantago performance and chemistry. Ecology 74:1778-1791DOI: 10.2307/1939936.

Connan S, Goulard F, Stiger V, Deslandes E, Ar Gall E. 2004. Interspecific and temporal variation in phlorotannin levels in an assemblage of brown algae. Botanica Marina 47:410-416 DOI 10.1515/BOT.2004.057.

Cruces E, Huovinen P, Gómez I. 2012. Phlorotannin and antioxidant responses upon short-term exposure to UV radiation and elevated temperature in three South Pacific kelps. Photochemistry and Photobiology 88:58-66 DOI 10.1111/j.1751-1097.2011.01013.x.

Cruces E, Huovinen P, Gómez I. 2013. Interactive effects of UV radiance and enhanced temperature on photosynthesis, phlorotannin induction and antioxidant activities of two sub-Antarctic brown algae. Marine Biology 160:1-13 DOI 10.1007/s00227-012-2049-8.

Denton A, Chapman ARO, Markham J. 1990. Size-specific concentrations of phlorotannins (anti-herbivore compounds) in three species of Fucus. Marine Ecology Progress Series 65:103-104.

Estes JA, Steinberg PD. 1988. Predation, herbivory and kelp evolution. Paleobiology 14:19-36.

Faugeron S, Martinez EA, Correa JA, Cardenas L, Destombe C, Valero M. 2004. Reduced genetic diversity and increased population differentiation in peripheral and overharvested populations of Gigartina skottsbergii (Rhodophyta, Gigartinales) in southern Chile. Journal of Phycology 40:454462 DOI 10.1111/j.1529-8817.2004.03114.x.

Faugeron S, Valero M, Destombe C, Martínez EA, Correa JA. 2001. Hierarchical spatial structure and discriminant analysis of genetic diversity in the red alga Mazzaella laminarioides (Gigartinales, Rhodophyta). Journal of Phycology 37:705-716 DOI 10.1046/j.1529-8817.2001.01072.x.

Fleury BG, Kelecom A, Pereira RC, Teixeira VL.1994. Polyphenols, terpenes and sterols in Brazilian Dictyotales and Fucales (Phaeophyta). Botanica Marina 37:457-462 DOI 10.1515/botm.1994.37.5.457.

Floeter SR, Soares-Gomes A. 1999. Biogeographic and species richness patterns of gastropoda on the Southwestern Atlantic. Revista Brasileira de Biologia59:567-575.

Hay ME, Steinberg PD. 1992. The chemical ecology of plant-herbivore interactions in marine versus terrestrial communities. In: Rosenthal G, Berembaum M, eds. Herbivores: their interaction with secondary plant metabolites. Academic Press San Diego.

Hemmi A, Honkanen T, Jormalainen V. 2004. Inducible resistance to herbivory in Fucus vesiculosus - duration, spreading and variation with nutrient availability. Marine Ecology Progress Series 273:109-120 DOI $10.3354 /$ meps273109.

Henry BE, Van Alstyne KL. 2004. Effects of UV radiation on growth and phlorotannins in Fucus gardneri (Phaeophyceae) juveniles and embryos. Journal of Phycology 40:527-533 DOI 10.1111/j.15298817.2004.03103.x.

Jennings JG, Steinberg PD. 1994. In situ exudation of phlorotannins by the sublittoral kelp Ecklonia radiata. Marine Biology 121:349-354 DOI 10.1007/BF00346744.

Jormalainen V, Ramsay T. 2009. Resistance of the brown alga Fucus vesiculosus to herbivory. Oikos 118:713-722 DOI 10.1111/j.1600-0706.2008.17178.x.

Jormalainen V, Honkanen T, Koivikko R, Eränen A. 2003. Induction of phlorotannin production in a brown alga: defense or resource dynamics? Oikos 103:640-650 DOI 10.1034/j.1600-0706.2003.12635.x. 
Jormalainen V, Honkanen T. 2008. Macroalgal chemical defenses and their roles in structuring temperate marine communities. In: Amsler CD, ed. Algal chemical ecology. Springer-Verlag Berlin, Heidelberg, Germany.

Kamiya M, Nishio T, Yokoyama A, Yatsuya K, Nishigaki T, Yoshikawa S, Ohki K. 2010. Seasonal variation of phlototannin in sargassacean species from the coast of the Sea of Japan. Phycological Research 58:53-61 DOI 10.1111/j.1440-1835.2009.00558.x.

Karez CS, Pereira R. C. 1995. Metal contents in polyphenolic fractions extracted from the brown alga Padina gymnospora. Botanica Marina 38:151-155 DOI 10.1515/botm.1995.38.1-6.151.

Katayama T. 1951. Tannins of seaweeds. Journal of the Society of Chemical Industry 54:603-604.

Koivikko R, Loponen J, Jormalainen V. 2008. Variation of phlorotannins among three populations of Fucus vesiculosus as revealed by HPLC and colorimetric quantification. Journal Chemical Ecology 34:57-64 DOI 10.1007/s10886-007-9410-2.

Koivikko R, Loponen J, Honkanen T, Jormalainen V. 2005. Contents of soluble, cell-wall-bound and exuded phlorotannins in the brown alga Fucus vesiculosus, with implications on their ecological functions. Journal Chemical Ecology 31:195-212 DOI 10.1007/s10886-005-0984-2.

Koivikko R, Loponen J, Pihlaja K, Jormalainen, V. 2007. High-Performance Liquid Chromatographic analysis of phlorotannins from the brown alga Fucus vesiculosus. Phytochemical Analisys 18:326-332 DOI 10.1002/pca.986.

Longo GO, Ferreira CEL, Floeter SR. 2014. Herbivory drives large-scale spatial variation in reef fish trophic interactions. Ecology andEvolution 4:4553-4566 DOI 10.1002/ece3.1310.

Masuda M, Abe T, Sato S. 1997. Diversity of halogenated secondary metabolites in the red alga Laurencia nipponica (Rhodomelaceae, Ceramiales). Journal of Phycology 33:196-208 DOI 10.1111/j.00223646.1997.00196.x.

Matlock DB, Ginsburg DW, Paul VJ. 1999. Spatial variability in secondary metabolite production by the tropical red alga Portieria hornemannii. Hydrobiologia 398/399:267-273 DOI 10.1023/A:1017003522096.

Nishihara GN, Terada R, Noro T. 2004. Photosynthesis and growth rates of Laurencia brongniartii J. Agardh (Rhodophyta, Ceramiales) in preparation for cultivation. Journal of Applied Phycology 16:303-308 DOI 10.1023/B:JAPH.0000047790.59265.fb.

Oliveira AS, Sudatti DB, Fujii MT, Rodrigues SV, Pereira RC. 2013. Inter- and intrapopulation variation in the defensive chemistry of the red seaweed Laurencia dendroidea (Ceramiales, Rhodophyta). Phycologia 52:130-136. DOI 10.2216/12-058.1.

Padilla-Gamiño JL, Carpenter RC. 2007. Thermal ecophysiology of Laurencia pacifica and Laurencia nidifica (Ceramiales) from tropical and warm-temperate regions. Journal of Phycology 43:686-692 DOI 10.1111/j.1529-8817.2007.00362.x.

Paul VJ, Van Alstyne KL. 1988. Chemical defense and chemical variation in some tropical Pacific species of Halimeda (Chlorophyta, Halimedaceae). Coral Reefs 6:263-270 DOI 10.1007/BF00302022.

Pavia H, Toth GB. 2000. Influence of light and nitrogen on the phlorotannin content of the brown seaweeds Ascophyllum nodosum and Fucus vesiculosus. Hydrobiologia 440:299-305 DOI 10.1023/A:1004152001370.

Pavia H, Cervin G, Lindgren A, Aberg P. 1997. Effects of UV-B radiation and simulated herbivory on phlorotannins in the brown alga Ascophyllum nodosum. Marine Ecology Progress Series 157:139-146 DOI 10.3354/meps157139.

Pavia H, Toth GB, Lindgren A, Åberg P. 2003. Intraspecific variation in the phlorotannin content of the brown alga Ascophyllum nodosum. Phycologia 42: 378-383 DOI 10.2216/10031-8884-42-4-378.1.

Pereira RC, Da Gama BAP. 2008. Macroalgal chemical defenses and their roles in structuring tropical marine communities. In: Amsler CD, ed. Algal chemical ecology. London, Springer.

Pereira RC, Yoneshigue-Valentin Y. 1999. The role of polyphenols from tropical brown alga Sargassum furcatum on the feeding by amphipod herbivores. Botanica Marina 42:441-444 DOI 10.1515/BOT.1999.051. 
Pereira RC, Yoneshigue-Valentin Y, Teixeira VL, Kelecom A. 1990. Phlorotannins in Brazilian brown algae: quantitative study and ecological implications. Planta Medica 56:557-558 DOI 10.1055/s-2006-96114.

Plouguerné E, Hellio C, Cesconetto C, Thabard M, Mason K, Véron B, Pereira R C, Da Gama BAP. 2010. Antifouling activity as a function of population variation in Sargassum vulgare from the littoral of Rio de Janeiro (Brazil). Journal of Applied Phycology 22:717-724 DOI 10.1007/s10811-010-9511-0.

Plouguerné E, Cesconetto C, Cruz CP, Pereira RC, Da Gama BAP. 2012. Within-thallus variation in polyphenolic content and antifouling activity in Sargassum vulgare. Journal of Applied Phycology 24:1629-1635 DOI 10.1007/s10811-012-9826-0.

Puglisi MP, Paul VJ. 1997. Intraspecific variation in the red alga Portieria hornemannii: monoterpene concentrations are not influenced by nitrogen or phosphorus enrichment. Marine Biology 128:161-170 DOI $10.1007 / \mathrm{s} 002270050079$.

Ragan MA, Glombitza KW. 1986. Phlorotannins, brown algal polyphenols. In: Round FE, Chapman DJ, ed. Progress in Phycological Research, Biopress, Bristol, United Kingdom.

Railkin, AI. 2004. Marine biofouling: colonization processes and defenses. CRC, Boca Raton, FL.

Santelices B. 1990. Patterns of reproduction, dispersal and recruitment in seaweeds. Oceanography and Marine Biology Annual Review 28:177-276.

Schoenwaelder MEA. 2002. The occurrence and cellular significance of physodes in brown algae. Phycologia 41:125-139 DOI 10.2216/i0031-8884-41-2-125.1.

Schoenwaelder MEA, Clayton MN. 1999. The presence of phenolic compounds in isolated cell walls of brown algae. Phycologia 38:161-166 DOI 10.2216/i0031-888-38-3-161.1.

Sosa PA, Garcia-Reina G. 1993. Genetic variability of Gelidium canariensis determined by isozyme electrophoresis. Journal of Phycology 29:118-124 DOI 10.1111/j.1529-8817.1993.tb00289.x.

Steinberg PD. 1985. Feeding preferences of Tegula funebralis and chemical defenses of marine brown algae. Ecological Monograph 5: 333-349 DOI 10.2307/1942581.

Steinberg PD. 1986. Chemical defenses and the susceptibility of tropical marine brown algae to herbivores. Oecologia 69:628-630 DOI 10.1007/BF00410374.

Steinberg PD. 1988. Effects of quantitative and qualitative variation in phenolic compounds on feeding in three species of marine invertebrate herbivores. Journal of Experimental Marine Biology and Ecology 120:221237 DOI 10.1016/0022-0981(88)90003-2.

Steinberg PD. 1989. Biogeographical variation in brown algal polyphenolics and other secondary metabolites: comparison between temperate Australasia and North America. Oecologia 78:373-382 DOI 10.1007/BF00379112.

Steinberg PD. 1992. Geographical variation in the interaction between marine herbivores and brown algal secondary metabolites. In: Paul VJ, ed. Marine chemical ecology. Cornell Press, New York.

Steinberg PD, Paul VJ. 1990. Fish feeding and chemical defenses of tropical brown algae in Western Australia. Marine Ecology Progress Series 58:253-259 DOI 10.3354/meps058253.

Steinberg PD, Van Altena IA. 1992. Tolerance of marine invertebrate herbivores to brown algal phlorotannins in temperate Australasia. Ecological Monograph 62:189-222 DOI 10.2307/2937093.

Sudatti DB, Rodrigues SV, Pereira RC. 2006. Quantitative GC-ECD analysis of halogenated metabolites: determination of elatol on surface and within-thallus of Laurencia obtusa. Journal of Chemical Ecology 32:835-843 DOI 10.1007/s10886-006-9033-z.

Sudatti DB, Fujii MT, Rodrigues SV, Turra A, Pereira RC. 2011. Effects of abiotic factors on growth and chemical defenses in cultivated clones of Laurencia dendroidea J. Agardh (Ceramiales, Rhodophyta). Marine Biology 158:1439-1446 DOI 10.1007/s00227-011-1660-4.

Targett NM, Arnold TM. 1998. Predicting the effects of brown algal phlorotannins on marine herbivores in tropical and temperate oceans. Journal of Phycology 34:195-205 DOI 10.1046/j.1529-8817.1998.340195.x.

Targett NM, Arnold TM. 2001. Effects of secondary metabolites on digestion in marine herbivores. In: McClintock JB, Baker BJ, eds. Marine chemical ecology CRC Press, Boca Raton, USA. 
Targett NM, Boettcher AA, Targett TE, Vrolijk NH. 1995. Tropical marine herbivore assimilation of phenolicrich plants. Oecologia 103:170-179 DOI 10.1007/BF00329077.

Targett NM, Coen LD, Boettcher AA, Tanner CE. 1992. Biogeographic comparisons of marine algal polyphenolics: evidence against a latitudinal trend. Oecologia 89:464-470 DOI 10.1007/BF00317150.

Tatarenkov A, Jonsson RB, Kautsky L, Johannesson K. 2007. Genetic structure in populations of Fucus vesiculosus (Phaeophyceae) over spatial scales from $10 \mathrm{~m}$ to $800 \mathrm{~km}$. Journal of Phycology 43:675-685 DOI 10.1111/j.1529-8817.2007.00369.x.

Tsai CC, Cheng JS, Sheu F, Shyu YT, Yu AYC, Wong SL, Dai CF, Lee TM. 2005. Seasonal growth dynamics of Laurencia papillosa and Gracilaria coronopifolia from a highly eutrophic reef in southern Taiwan: temperature limitation and nutrient availability. Journal of Experimental Marine Biology and Ecology 315:49-69 DOI 10.1016/j.jembe.2004.08.025.

Tugwell S, Branch GM. 1989. Differential polyphenolic distribution among tissues in the kelps Ecklonia maxima, Laminaria pallida and Macrocystis angustifolia in relation to plant-defence theory. Journal of Experimental Marine Biology and Ecology129:219-230 DOI 10.1016/0022-0981(89)90104-4.

Van Alstyne KL. 1988. Herbivore grazing increases polyphenolic defenses in the intertidal brown alga Fucus distichus. Ecology 69:655-663 DOI 10.2307/1941014.

Van Alstyne KL, Paul V. J. 1990. The biogeography of polyphenolic compounds in marine macroalgae: temperate brown algal defenses deter feeding by tropical herbivorous fishes. Oecologia 84:158-163 DOI 10.1007/BF00318266.

Van der Strate HJ, Van de Zande L, Stam WT, Haroun RJ, Olsen JL. 2003. Within-island differentiation and between-island homogeneity: non-equilibrium population structure in the seaweed Cladophoropsis membranacea (Chlorophyta) in the Canary Islands. European Journal of Phycology 38:15-23 DOI $10.1080 / 0967026031000096218$.

Weidner K, Lages BG, Da Gama BAP, Molis M, Wahl M, Pereira RC. 2004. Effects of mesograzer and nutrient levels on the induction of defenses in several Brazilian macroalgae. Marine Ecology Progress Series 283:113-125 DOI 10.3354/meps283113.

Wright JT, De Nys R, Poore AGB, Steinberg PD. 2004. Chemical defense in a marine alga: heritability and the potential for selection by herbivores. Ecology 85:2946-2959 DOI 10.1890/03-4041.

Wright JT, De Nys R, Steinberg PD. 2000a. Geographic variation in halogenated furanones from the red alga Delisea pulchra and associated herbivores and epiphytes. Marine Ecology Progress Series 207:227-241 DOI 10.3354/meps207227.

Wright JT, Zuccarello GC, Steinberg PD. 2000b. Genetic structure of the subtidal red alga Delisea pulchra. Marine Biology 136:439-448 DOI 10.1007/s002270050703.

Verges A, Paul NA, Steinberg PD. 2008. Sex and life-history stage alter herbivore responses to a chemically defended red alga. Ecology 89:1334-1343 DOI 10.1890/07-0248.1.

Zuccarello G, Sandercock B, West J. 2001. Diversity within red algal species: variation in world-wide samples of Spyridia filamentosa (Ceramiaceae) and Murrayella periclados (Rhodomelaceae) using DNA markers and breeding studies. European Journal of Phycology 37:403-417 DOI 10.1017/S0967026202003827. 
Figure 1

Sampling sites

Sampling sites of collect of the brown seaweeds studied along the Brazilian littoral, in a latitudinal range of $21^{\circ}$.

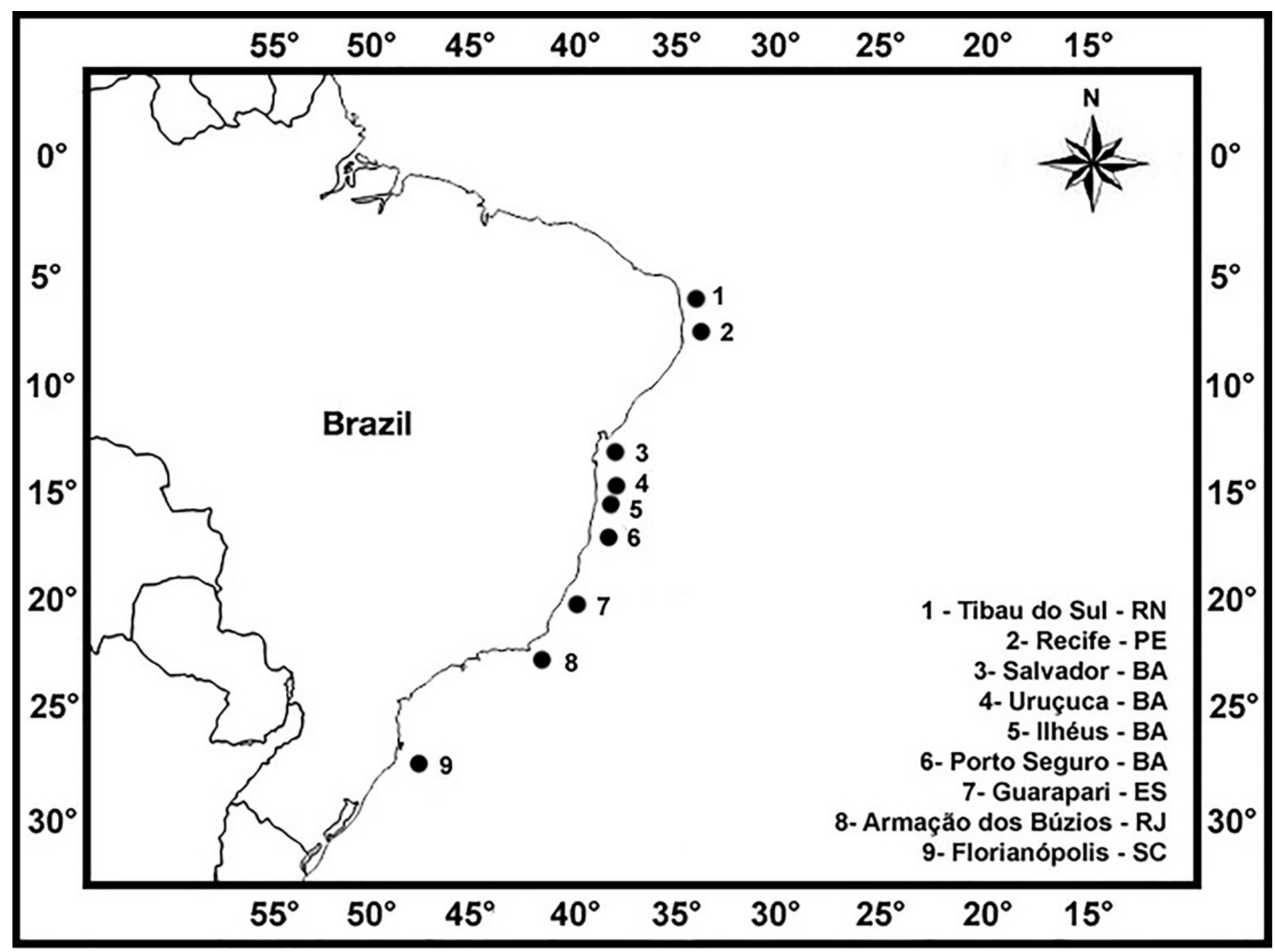


Figure 2

Correlation: coefficient of variation (\%) in content of phlorotannins and latitude

Correlation between the coefficient of variation (\%) in content of phlorotannins found in brown seaweeds and latitude (sampling site of the seaweeds).

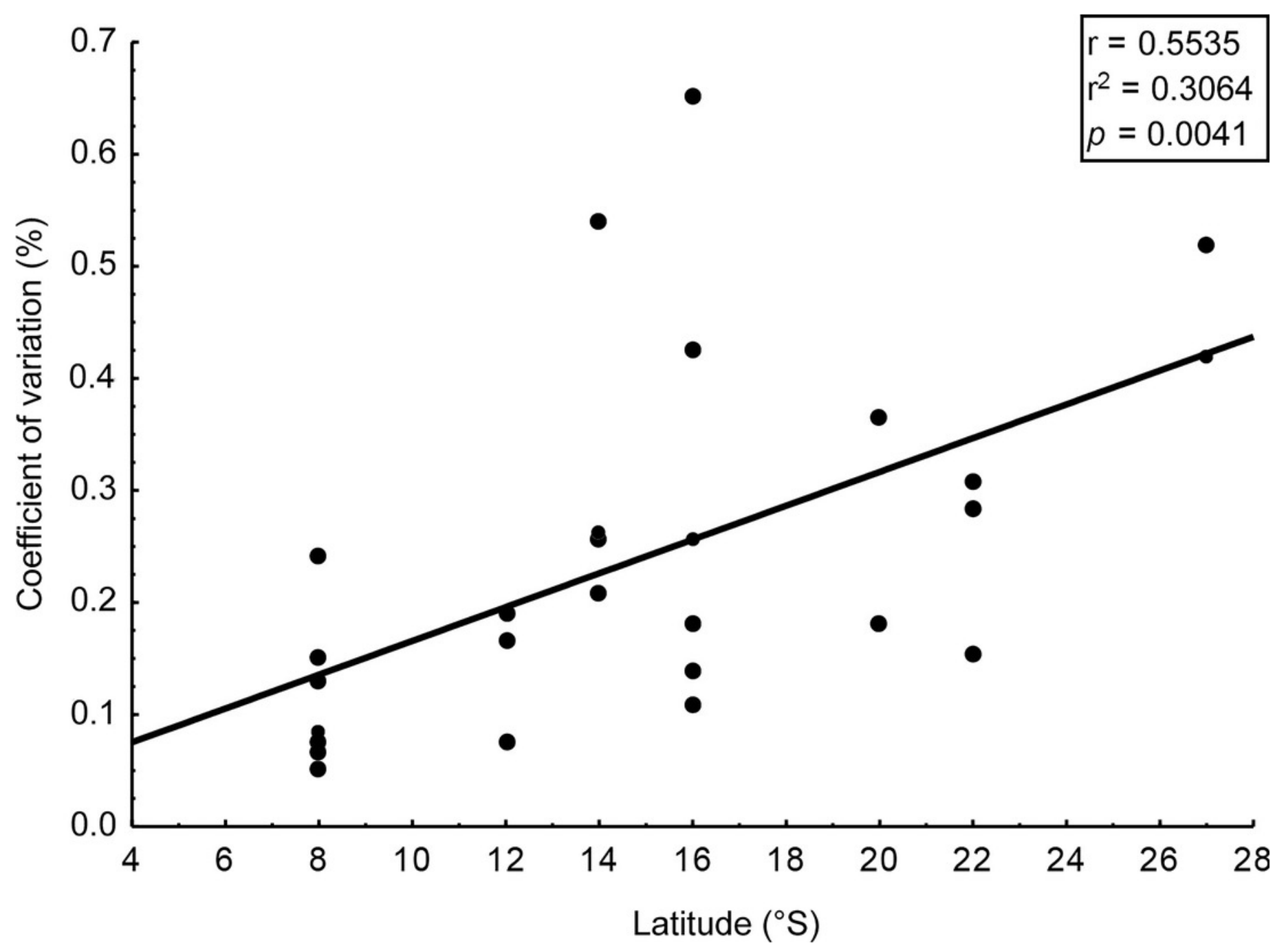


Figure 3

Correlation: total content of phlorotannins $\mathrm{x}$ latitude.

Correlation between total content of phlorotannins found in the brown seaweeds and latitude(sampling site of the seaweeds).

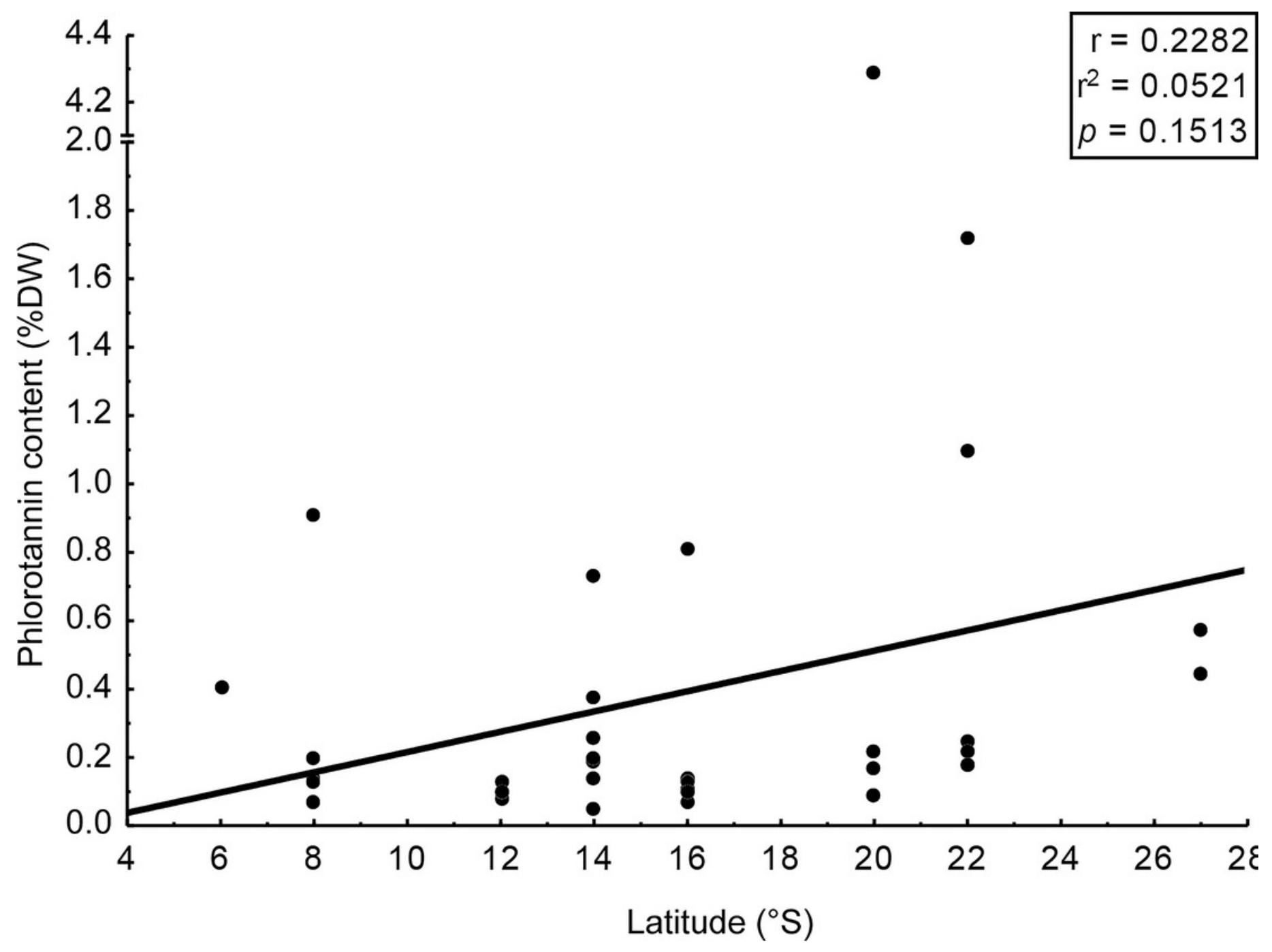




\section{Table $\mathbf{1}$ (on next page)}

Table 1

Brown seaweeds studied, number of specimens and corresponding collection places ( $x=$ The individuals were analyzed together because of the small size/biomass of the specimens; while in the remaining species, the analyzes were performed in each individual) 
1 Table 1. Brown seaweeds studied, number of specimens and corresponding collection places ( $\mathrm{x}=$ 2 The individuals were analyzed together because of the small size/biomass of the specimens; 3 while in the remaining species, the analyzes were performed in each individual)

4

\begin{tabular}{|c|c|c|c|c|c|c|c|c|c|}
\hline \multirow[t]{2}{*}{ Seaweed species } & \multicolumn{9}{|c|}{ Sampling sites } \\
\hline & 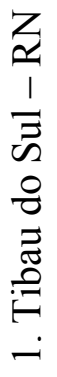 & 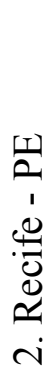 & $\begin{array}{l}\mathbb{\pi} \\
m \\
1 \\
\frac{0}{0} \\
\frac{\pi}{0} \\
\frac{\lambda}{\pi} \\
\dot{n} \\
\dot{n} \\
\dot{m}\end{array}$ & 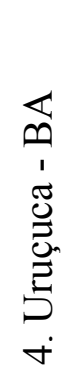 & 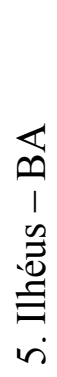 & 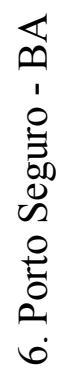 & 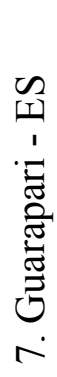 & 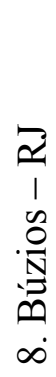 & 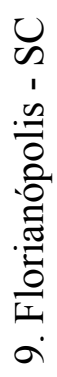 \\
\hline Canistrocarpus cervicornis & & 7 & & & & & & $\mathrm{x}$ & \\
\hline Colpomenia sinuosa & & & & & & 4 & & $\mathrm{X}$ & \\
\hline Dictyopteris delicatula & & 8 & 10 & & & $\mathrm{X}$ & $\mathrm{x}$ & & \\
\hline Dictyopteris polypodioides & & & & & & & $\mathrm{x}$ & & \\
\hline Dictyota ciliolata & & & & & & 11 & & & \\
\hline Dictyota crispata & & & & & & 19 & & & \\
\hline Dictyota dichotoma & & & & & & $\mathrm{x}$ & & & \\
\hline Dictyota mertensii & & 7 & & & & & $\mathrm{x}$ & 10 & \\
\hline Dictyota pfaffii & & & 10 & & & & & & \\
\hline Lobophora variegata & & 10 & $\mathrm{x}$ & & & 10 & & & \\
\hline Padina gymnospora & $\mathrm{x}$ & 10 & & $\mathrm{x}$ & $\mathrm{x}$ & 7 & $\mathrm{x}$ & $\mathrm{x}$ & 8 \\
\hline Sargassum filipendula & & & 9 & 10 & & & & & \\
\hline Sargassum ramifolium & & & & & & & 7 & & \\
\hline Sargassum stenophyllum & & & & & & & & & 7 \\
\hline Sargassum vulgare & & 15 & & 6 & 10 & 22 & & 5 & \\
\hline Spatoglossum schroederi & & & & & & & 10 & & \\
\hline Stypopodium zonale & & & & & & & & 32 & \\
\hline
\end{tabular}

5

6 


\section{Table 2 (on next page)}

\section{Table 2}

Number of individuals (N), and mean total phlorotannin content (TPC) measured in \% (average \pm standard deviation) of dry weight (DW) for the populations of seaweeds studied from different collection sites, including the coordinates, coefficient of variation (CV) and the ANOVA results for intra-populational variation (IV). 
1 Table 2. Number of individuals(N), and mean total phlorotannin content (TPC) measured in \%

2 (average \pm standard deviation) of dry weight (DW) for the populations of seaweeds studied from

3 different collection sites, including the coordinates, coefficient of variation (CV) and the ANOVA

4 results for intra-populational variation (IV).

\begin{tabular}{|c|c|c|c|c|c|c|c|}
\hline Seaweeds & Time of year & Location & Latitude ( $\left.{ }^{\circ} \mathrm{S}\right)$ & $\mathbf{N}$ & TPC (\%DW) & IV & CV (\%) \\
\hline C. cervicornis & Spring/09 & 2 & 8 & 7 & $0.13 \pm 0.01$ & $F=45.3 ; p<0.001$ & 8.5 \\
\hline C. cervicornis & Summer/11 & 9 & 22 & + & $0.18 \pm 0.00$ & + & + \\
\hline C. sinuosa & Summer/11 & 7 & 16 & 4 & $0.07 \pm 0.01$ & + & + \\
\hline C. sinuosa & Summer/11 & 9 & 22 & + & $0.24 \pm 0.02$ & + & + \\
\hline D. ciliolata & Summer/11 & 7 & 16 & 11 & $0.14 \pm 0.02$ & $F=126.3 ; p<0.001$ & 13.9 \\
\hline D. crispata & Summer/11 & 7 & 16 & 19 & $0.14 \pm 0.04$ & $F=646.9 ; p<0.001$ & 25.7 \\
\hline D. delicatula & Spring/09 & 2 & 8 & 8 & $0.14 \pm 0.01$ & $F=31.8 ; p<0.001$ & 7.7 \\
\hline D. delicatula & Summer/11 & 3 & 12 & 10 & $0.08 \pm 0.01$ & $F=6.8 ; p<0.001$ & 19.1 \\
\hline D. delicatula & Summer/11 & 7 & 16 & + & $0.13 \pm 0.01$ & + & + \\
\hline D. delicatula & Summer/11 & 8 & 20 & + & $0.12 \pm 0.02$ & + & + \\
\hline D. dichotoma & Summer/11 & 7 & 6 & + & $0.11 \pm 0.01$ & + & + \\
\hline D. mertensii & Spring/09 & 2 & 8 & 7 & $0.19 \pm 0.01$ & $F=15.7 ; p<0.001$ & 5.2 \\
\hline D. mertensii & Summer/11 & 8 & 20 & + & $0.10 \pm 0.01$ & + & + \\
\hline D. mertensii & Summer/11 & 9 & 22 & 10 & $0.18 \pm 0.03$ & $F=73.9 ; p<0.001$ & 15.4 \\
\hline D. pfaffii & Summer/11 & 3 & 12 & 10 & $0.10 \pm 0.02$ & $F=34.1 ; p<0.001$ & 16.6 \\
\hline D. polypodioides & Summer/11 & 8 & 20 & + & $0.22 \pm 0.01$ & + & + \\
\hline L. variegata & Spring/09 & 2 & 8 & 10 & $0.91 \pm 0.22$ & $F=366.0 ; p<0.001$ & 24.1 \\
\hline L. variegata & Summer/11 & 3 & 2 & + & $0.13 \pm 0.00$ & + & + \\
\hline L. variegata & Summer/11 & 7 & 16 & 10 & $0.81 \pm 0.53$ & $F=3765.0 ; p<0.001$ & 65.3 \\
\hline P. gymnospora & Autumn/11 & 1 & 6 & + & $0.40 \pm 0.02$ & + & + \\
\hline P. gymnospora & Spring/09 & 2 & 8 & 10 & $0.07 \pm 0.01$ & $F=58.1 ; p<0.001$ & 13.1 \\
\hline P. gymnospora & Summer/11 & 4 & 14 & + & $0.19 \pm 0.01$ & + & + \\
\hline P. gymnospora & Summer/11 & 5 & 14 & + & $0.26 \pm 0.02$ & + & + \\
\hline P. gymnospora & Summer/11 & 6 & 14 & + & $0.05 \pm 0.00$ & + & + \\
\hline
\end{tabular}




\begin{tabular}{|c|c|c|c|c|c|c|c|}
\hline P. gymnospora & Summer/11 & 7 & 16 & 7 & $0.13 \pm 0.05$ & $F=127.3 ; p<0.001$ & 42.7 \\
\hline P. gymnospora & Summer/11 & 8 & 20 & + & $0.09 \pm 0.02$ & + & + \\
\hline P. gymnospora & Summer/11 & 9 & 22 & + & $0.22 \pm 0.09$ & + & + \\
\hline P. gymnospora & Autumn/10 & 10 & 7 & 8 & $0.58 \pm 0.30$ & $F=802.3 ; p<0.001$ & 51.8 \\
\hline S. filipendula & Summer/11 & 3 & 12 & 9 & $0.09 \pm 0.00$ & $F=48.9 ; p<0.001$ & 7.6 \\
\hline S. filipendula & Summer/11 & 4 & 14 & 10 & $0.38 \pm 0.10$ & $F=1166.8 ; p<0.001$ & 25.6 \\
\hline S. ramifolium & Summer/11 & 8 & 20 & 7 & $0.17 \pm 0.06$ & $F=166.5 ; p<0.001$ & 36.5 \\
\hline S. schroederi & Summer/11 & 8 & 20 & 10 & $4.30 \pm 0.78$ & $F=180.1 ; p<0.001$ & 18.1 \\
\hline S. stenophyllum & Autumn/10 & 10 & 27 & 7 & $0.45 \pm 0.19$ & $F=109.9 ; p<0.001$ & 42.0 \\
\hline S. vulgare & Spring/09 & 2 & 8 & 15 & $0.13 \pm 0.01$ & $F=85.8 ; p<0.001$ & 9.6 \\
\hline S. vulgare & Summer/11 & 4 & 14 & 6 & $0.14 \pm 0.04$ & $F=4335.0 ; p<0.001$ & 26.3 \\
\hline S. vulgare & Summer/11 & 5 & 14 & 12 & $0.73 \pm 0.15$ & $F=90.5 ; p<0.001$ & 20.7 \\
\hline S. vulgare & Summer/11 & 6 & 14 & 10 & $0.20 \pm 0.11$ & $F=1428.1 ; p<0.001$ & 53.9 \\
\hline S. vulgare & Summer/11 & 7 & 16 & 10 & $0.10 \pm 0.02$ & $F=89.9 ; p<0.001$ & 18.1 \\
\hline S. vulgare & Summer/11 & 9 & 22 & 5 & $1.10 \pm 0.31$ & $F=212.8 ; p<0.001$ & 30.9 \\
\hline S. zonale & Summer/12 & 9 & 22 & 32 & $1.72 \pm 0.49$ & $F=37.2 ; p<0.001$ & 28.3 \\
\hline
\end{tabular}

5 1. Tibau do Sul; 2. Recife; 3. Salvador; 4. Uruçuca; 5. Ilhéus (Morro de Pernambuco); 6. Ilhéus (Back 6 Door); 7. Porto Seguro; 8. Guarapari; 9. Armação dos Búzios; 10. Florianópolis.

$7 \quad *$ Insufficient biomassfor individual analysis. 